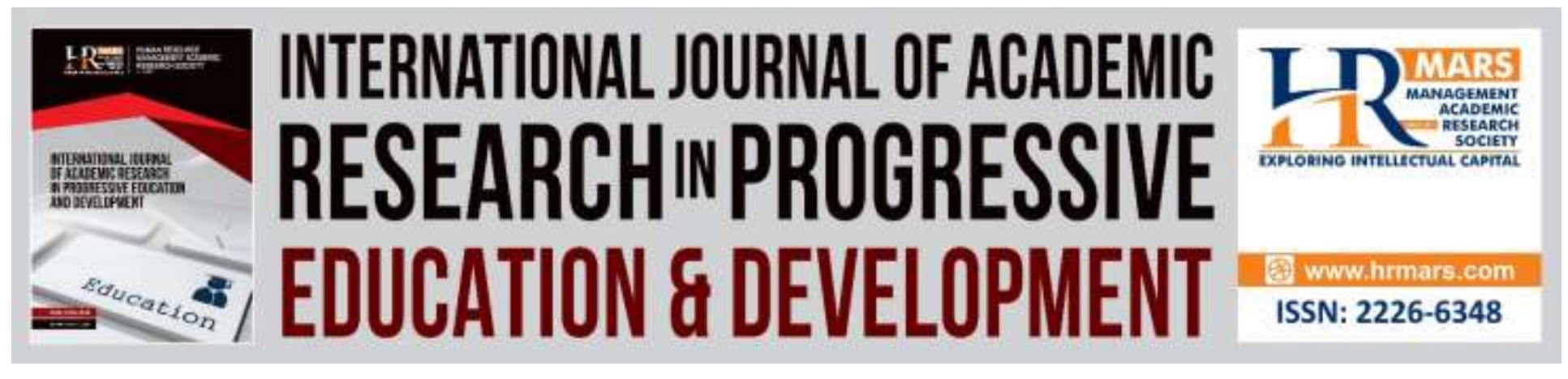

\title{
Visual Aids to Construct Sentences Using Preposition among ILP Students
}

\author{
S Arulla A/P Sitiray, Jamalul Lail Abdul Wahab, Shobaa Mennon A/P \\ Narayanan
}

To Link this Article: http://dx.doi.org/10.6007/IJARPED/v8-i3/6427

DOI: 10.6007/IJARPED/v8-i3/6427

Received: 18 July 2019, Revised: 17 August 2019, Accepted: 09 September 2019

Published Online: 15 September, 2019

In-Text Citation: (Sitiray, Wahab, \& Narayanan, 2019)

To Cite this Article: Sitiray, S. A. A., Wahab, J. L. A., \& Narayanan, S. M. A. (2019). Visual Aids to Construct Sentences Using Preposition among ILP Students. International Journal of Academic Research in Progressive Education and Development, 8(3), 335-342.

\section{Copyright: (C) 2019 The Author(s)}

Published by Human Resource Management Academic Research Society (www.hrmars.com)

This article is published under the Creative Commons Attribution (CC BY 4.0) license. Anyone may reproduce, distribute, translate and create derivative works of this article (for both commercial and non-commercial purposes), subject to full attribution to the original publication and authors. The full terms of this license may be seen

at: http://creativecommons.org/licences/by/4.0/legalcode

Vol. 8(3) 2019, Pg. 335 - 342

Full Terms \& Conditions of access and use can be found at http://hrmars.com/index.php/pages/detail/publication-ethics 


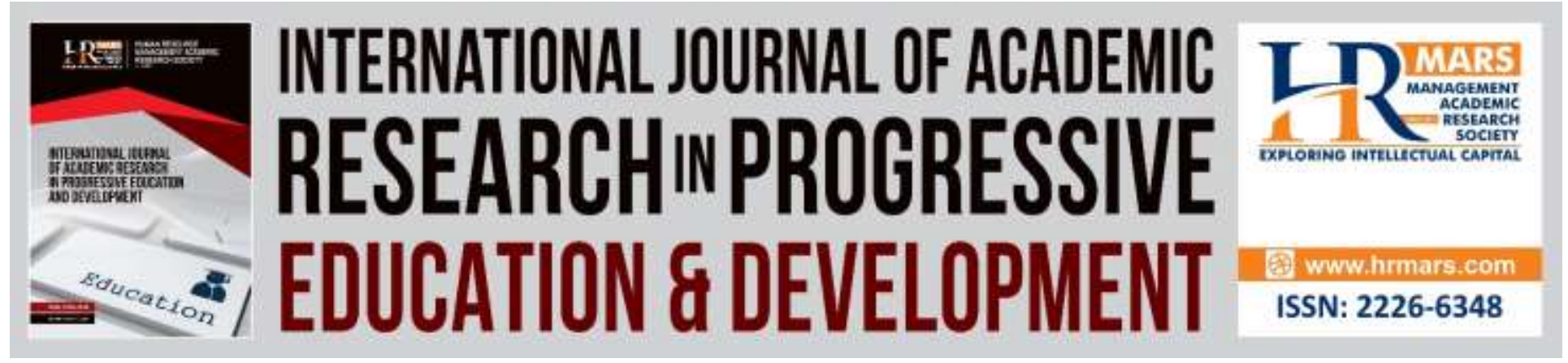

\title{
Visual Aids to Construct Sentences Using Preposition among ILP Students
}

\section{S Arulla A/P Sitiray, Jamalul Lail Abdul Wahab, Shobaa Mennon A/P Narayanan}

Faculty of Education, Universiti Kebangsaan Malaysia, ${ }^{2}$ Institut Latihan Perindustrian Email: P94367@siswa.ukm.edu.my

\begin{abstract}
This study was conducted to determine the use of flash card as visual learning aids to increase the level of sentence construct using preposition. The main purpose of the study was to identify the students to write the correct preposition based on flash card as visual learning aids. The second purpose of the study was to identify the students able to complete the sentences with the correct preposition based on flash card as visual learning aids. The third purpose of the third study was to identify students writing the correct sentences using preposition based on flash card as visual learning aids. There are 15 ILP, Pedas students were involved in this study. Preliminary surveys have been conducted through pre-test. Data is collected through pre-test and post-test. Students answer for 30 questions which assisted with the picture for post-test. Data analysis based on pre-test and post-test showed student scores are improved. The findings show that the student understanding has increased to construct sentences using flash card as preposition based on visual learning aids. Students are also motivated and interact in the classroom to construct sentences. The use of flash card as visual learning aids encourages the students to learn on their own. Students also can remember the preposition learned for a long time. In summary, this study helps the students to correctly identify the preposition and increase the level of writing using the correct preposition.
\end{abstract}

Keyword: Visual Aids, Preposition, Motivation, Improve.

\section{Introduction}

English is a global language that students need to master. English proficiency is essential for exploring a new knowledge in the field of education and is needed for get a good job (Mamat, 2016). Today, the tertiary institutions focus on English in teaching and learning as a way of preparing students for the world of work. This means that the teaching and learning of an institution is an important in create a human model. Teaching and learning is systematically and dynamically managed to develop a new knowledge. In addition, it can create innovative and creative ideas (Male, 2016).Therefore, Educators should play an important role in planning and 
implementing teaching and learning effectively. This is because each individual is different in terms of intellectual abilities. Therefore, in this study I used flash card as visual learning aids as strategic for teaching and learning. Flash card as visual learning aids are interesting and help the students to associate something that has been learned. It will also encourage the students to recall what they learn and enhance their understanding of a topic (Mustaffa, 2007).

Therefore, English is a compulsory subject that all students in ILP need to take. This is because most of the students studying in ILP do not get excellent results in English. So, students will study English each semester until the end of their studies. English lesson will be taught for 20 weeks. Every week students will study English for 90 minutes only. Teaching and learning English for 90 minutes are not enough for students who have not achieved excellent results in The Malaysian Certificate of Education (SPM) examinations. The students involved in the study only get $C, D$ and $E$ in the SPM examination.

Other than that, students use Malay language to communicate and ask questions with lecturers. This is due to the use of Malay language during teaching and learning while in secondary school. This causes students weak in writing, communication and grammar. However, during teaching and learning the lecturer constantly corrects grammar in writing and communication. One of the repeated grammar problems is preposition. Students always use wrong prepositions while writing and speaking.

\section{Literature Review \\ Learning Theories by Piaget (1954)}

The learning theory by Piaget (1954) says that learning is a change in knowledge and stay in memory. Piaget says every child has a different developmental pattern. This causes children to have different cognitive abilities and developments even though they study in the same level (url: http://eprints.utm.my/id/eprint/6258/1/2.pdf). According to Pahliwandari (2016) if the level of cognitive development is high then the ability to processing so the received information will also be higher. Furthermore, Zaki (2012) states that learning style determines the level of understanding and knowledge learned. The appropriate learning style will help to remember the lessons learned. Then the lessons will be stored in short-term memory and processed before saving in long-term memory.

\section{Multiple Intelligence Theory}

Different learning styles can also be seen through the multiple intelligence theory by Howard Gardner (1983). According to Howard Gardner's book "Frame of Mind" states that humans have 8 different intelligences. It consists of verbal-linguistic, mathematical logic, visualspace, kinesthetic, music, interpersonal, intrapersonal and naturalist. Eight types of intelligence indicate that each individual has different learning styles. Students who tend to visual intelligence will like to learn through visual learning aids such as picture cards, diagrams, charts and videos can be used to teach visual intelligence students(https://education.cuportland.edu/blog/classroom-resources/multiple-intelligences-theory/).My research will use flash card as visual learning aids so that students can remember and understand the use of preposition. It will help them to make sentences by using prepositions. 
Vol. 8, No. 3, 2019, E-ISSN: 2226-6348 @ 2019 HRMARS

\section{Past Studies about using Visual Aids in Teaching and Learning}

There are previous studies conducted by researchers to prove visual learning aids to enhance the understanding and interest of students. The study by Shabiralyan et al (2015) proves that visual tools help to stimulate thinking and create a good learning environment. Furthermore, students can enhance their own understanding for the topic learned. Other than that, study by Patesan et al (2018) shows that well designed visual aid will stimulate and motivate students and improve the effectiveness of teaching and learning. Visual learning aids can explain ideas by associating with real life situations. In addition, the class will be more interactive and interesting. Students also can improve vocabulary, listening, speaking and writing skills. Visual aids will make the students more creative, enhance their thinking and help to remind the lessons in the long term. In addition, the findings of the study of Yahaya \& Rahman (2017) show that students are also more interested, focused, motivated to learn. Students also motivated in producing assignments given by lecturers. As a result, student's marks also improve after using visual aid in teaching and learning. Similarly, Cade et al. (2018) showed that student groups which using visual aids improve a lot than the student group which not use visual aids. Groups using visual aids can remember information quickly than groups that do not use visual aids. So, educators must identify student learning styles before planning their teaching and learning. This is because visual intelligence student will learn quickly, associate something with daily life, motivate, become more creative when use suitable visual aid for teaching and learning.

\section{Methodology \\ Research Design}

This study is an action research study which use model developed by Kemmis \& McTaggart (1988). Kemmis \& McTaggart proposes four steps for each cycle such as plan, action, observe and reflect.

\section{Procedure}

This study was involved students from Industrial Training Institute (ILP) Pedas. There are 15 first year students who Mechatronic majors was involved in this study. The instrument of study were include interviews, observations, pre-test and post-test. First, interviews were conducted among the lecture who teach English to know about the problem faced by the students. Second, observation was carried out during the study period to determine the involvement of students in the activities. Third, pre-test which contain 30 multiple choice question answered by the students. Fourth, post-test contain 15 multiple choice questions,10 questions fill in the blanks, and 5 question make sentences based on the picture. This study uses percentages to analyze student outcomes.

\section{Results and Discussion \\ Findings of Interview}

Results from interviews shows that students were weak in English subjects. This causes students use Malay language during teaching and learning in the classroom. However, lecturers encourage the students to speak in English. When students speak lecture found that the using of grammar is incorrect. But lecturers do not fail to correct the mistakes of students. Other than 
Vol. 8, No. 3, 2019, E-ISSN: 2226-6348 @ 2019 HRMARS

that, the students who get lower result in SPM studies in ILP. There are 3 student get C, 6 students gets $D$ and 6 student gets $E$ in SPM. This result shows that students are weak in English

Table 1: Students SPM English Result

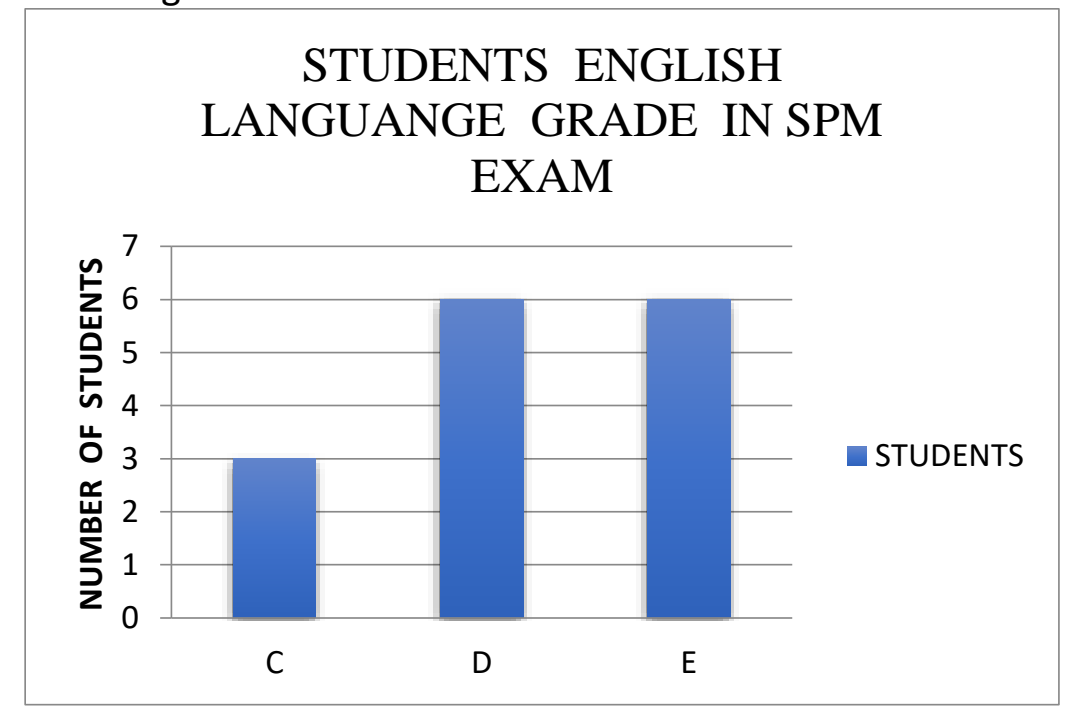

\section{Findings of Observation}

I have made observations on student behavior during the teaching and learning process. During pre-test, the students are worried and not confident to answer the question. But while carrying out activities students participate and enjoy the activity. After flash card as visual learning aid used in the teaching and learning students answer more confident in answering posttest question. 
INTERNATIONAL JOURNAL OF ACADEMIC RESEARCH IN PROGRESSIVE EDUCATION AND DEVELOPMENT

Vol. 8, No. 3, 2019, E-ISSN: 2226-6348 @ 2019 HRMARS

\section{Pre-Test and Post Test Result}

Table 2: Pre-Test and Post-Test result

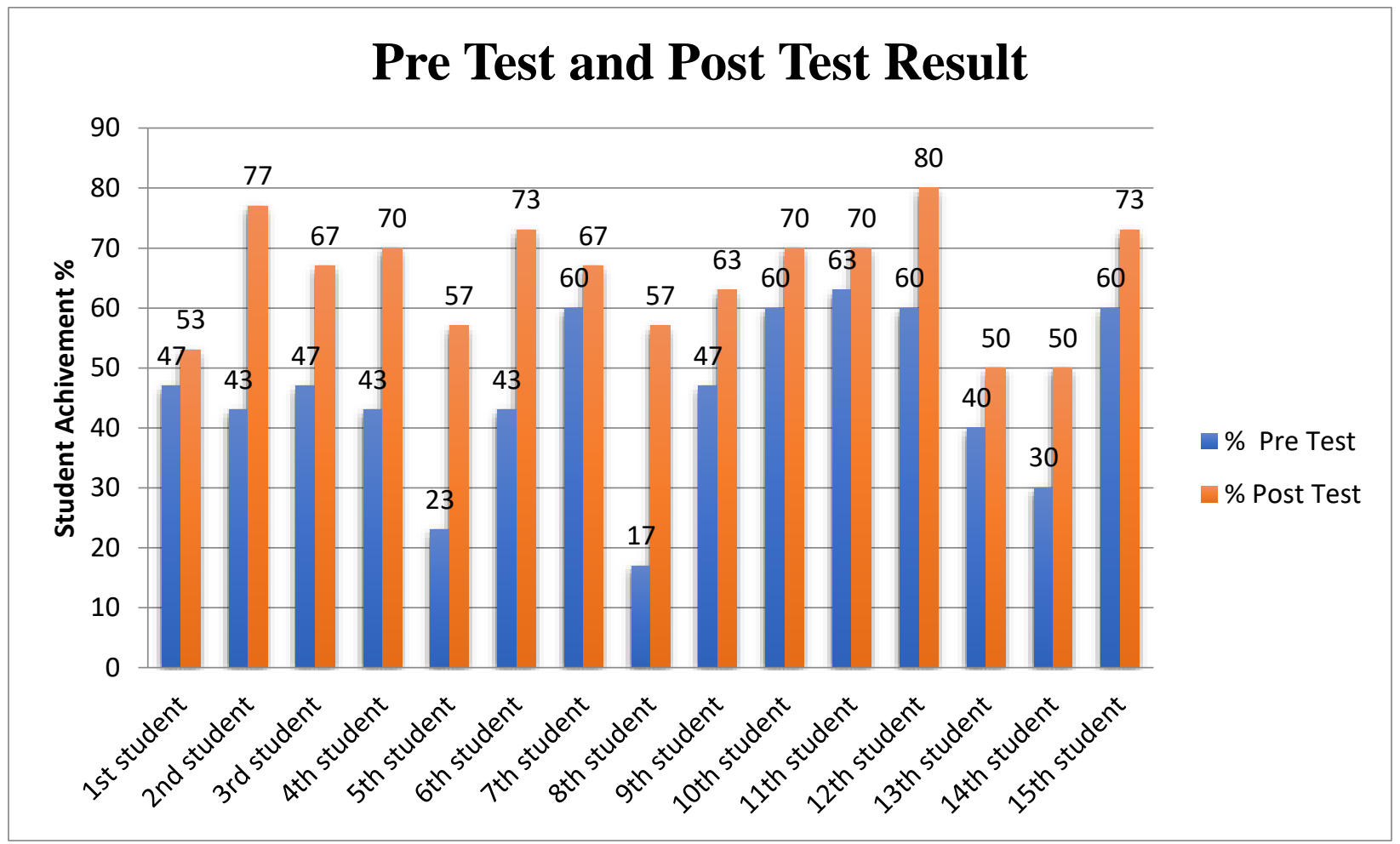

Analysis of Pre-test and post-test showed that 15 students improve in post-test. There are 3 students get lower percentage during pre-test. But the three students result is improve during post-test. $8^{\text {th }}$ student, $5^{\text {th }}$ student and $14^{\text {th }}$ student shows increase in their percentage like other students. It shows flash card as visual aid help the student to improve the level of construct sentences using prepositions. The $11^{\text {th }}$ students get highest mark in pre-test. But the $12^{\text {th }}$ student get highest marks in post-test. The $2^{\text {nd }}$ student, $4^{\text {th }}$ student, $6^{\text {th }}$ student, 8 th student shows good improvement in post- test. But $1^{\text {st }}$ student, $7^{\text {th }}$ student, $13^{\text {th }}$ students only got less improvement in their post-test. However, all students result got improvement after using flashcard as visual aid in teaching and learning.

\section{Conclusion}

\section{Summary of Findings}

The first activity of this study was started by pre-test. Pre-test contains 30 objective questions without pictures. The purpose of the pre-test is to find out the prior knowledge of preposition. After getting pre-test result, first activity was planned to use flash card to teach preposition. Flash card are chosen to teach preposition because based on Multiple Intelligence Theory by Howard Gardner (1983) students able to understand easy with the picture. In addition, visual learning through pictures will create a good learning environment. Students can also enhance their understanding of preposition learning with picture (Shaniralyan et al. 2015). 
Next, Let's Try the activity has been carried out. This activity is a game where student chooses a picture by turning the dice. Games are activities that can enhance student imagination. Students also can express ideas, concepts and desires with creativity (Fauziah, 2010; Matarid, Sobh, \& Ahmed, (2018).According to Piaget's cognitive theory, if the level of cognitive development is high, the ability is to process the information received will also be higher (Pahliwandari, 2016; Sangakala, Ahmed, \& Pahi, 2016). When playing student will play with fun. Student chooses a picture and say the correct preposition for every picture. Students also contract sentences correctly. This proves that the information received will be higher with the game method by using visual learning aids.

Finally post test score increase after using flash card as a visual learning aid. This is because the students have understood the concept of preposition through flash card and reinforced with a game which contain picture card. Piaget's cognitive theory proves a person's learning style will determine the level of understanding and knowledge. The appropriate learning style will help the lessons learned keep in the memory (Zaki, 2012). As a conclusion, flash card as visual learning aids are important for students to understand preposition clearly. Flash card as visual learning aids create a cheerful atmosphere and students focus on their learning. Flash card as visual learning aids also motivate students to ask questions in English.

\section{References}

Cade, A., Sherson, M., Holt, K., Dobson, G., Pritcharrd, K., \& Haavik, H. (2018). Differences in Deakin University Press.

Education. International conference Knowledge Based Organization, 24(2), 356-361.

Gardner, H. (1983). Frames of mind. The Theory of Multiple Intelligence. New York: Basic

Jaafar, F. M. (2008). Kepentingan Aktiviti Bermain Di Dalam Pendidikan Prasekolah. kemahiran Mara Johor Bahru. Laporan Projek Sarjana.UTHM.

Kemmis, S. \& McTaggart, R. (1988). The action research plannner. Geelong, Victoria, Australia: Khan. Journal of Education and Practice,6(19). 226-233.

Learning Retention When Teaching a manual motor skill with a visual vs written instruction aide. Journal of Chiropractic Education, 32(2), 107-114.

Mamat, M. (2016). The Command Of The English Language Among First-Year Undergraduate

Matarid, N. M., Sobh, O. S., \& Ahmed, U. (2018). The Impact of Organizational Justice and Demographics on Faculty Retention in Bahrain. Le travail humain, (3).

Mustaffa, R. (2007). "Stretching" ESL Learner's Learning Style: A Case Study of first Year Undergraduates at UKM. GEMA ONLINE journal of Language Studies. Volume 7(1)

of Visual Aids in Enhancing the learning process Case research: District Dera Ghazi

Pahliwandari, R. (2016). Penerapan Teori Pembelajaran Kognitif dalam Pembelajaran

Patesan, M. Balagv, A., \& Alibec, C. (2018). Visual Aids in Language

Pendidikan Jasmani dan Kesihatan. Jurnal Pendidikan Olaraga, 5(2), 154-164.

Piaget, J. (1954). The Construction of Reality in The Child. New York: Basic Book

Sangakala, M., Ahmed, U., \& Pahi, M. H. (2016). Empirical investigating on the role of supervisor support, job clarity, employee training and performance appraisal in addressing job satisfaction of nurses. International Business Management, 10(23), 5481-5486.

Shabiralyan, G., Hasan. K. S., Hamad, N. \& Iqbal, N. (2015). Impact 
INTERNATIONAL JOURNAL OF ACADEMIC RESEARCH IN PROGRESSIVE EDUCATION AND DEVELOPMENT

Vol. 8, No. 3, 2019, E-ISSN: 2226-6348 @ 2019 HRMARS

Students In UKM. Issues in Language Studies.5(2),28-42.

visual of commercial planning standard oleh pelajar Diploma Perancanagan Bandar dan Yahaya, F., \& Rahman, A. M. S. A. (2017). Keberkesanan Kefahaman Penggunaan Model Zaki, M. (2012). Gaya Pembelajaran Yang domain dalam kalangan pelajar di Institut 